\title{
A comparison of mollusc diversity between the relatively pristine Marico River and the impacted Crocodile River, two major tributaries of the Limpopo River, South Africa
}

\author{
Mathilde Kemp ${ }^{1 *}$, Kenné N de Kock ${ }^{1}$, Jazelle L Zaayman' and Cornelius T Wolmarans ${ }^{1}$ \\ 'Unit for Environmental Sciences and Management, Potchefstroom Campus of the North-West University, Private Bag X6001, Potchefstroom 2520,
} South Africa.

\begin{abstract}
A study of the freshwater mollusc diversity was conducted at selected sites in the relatively pristine Marico River and the impacted Crocodile River, the major tributaries of the Limpopo River. Four surveys were conducted, two in an early (May 2013 and 2014) and two in a late (November 2013 and 2014) low-flow period. Semi-quantitative surveys were done by sampling the vegetation, as well as the substratum, with a standard SASS net for approximately 15 min each. Environmental parameters including water temperature, electrical conductivity (EC) and $\mathrm{pH}$ were measured at each site. Molluscs were identified up to species level, sorted, counted, and the presence of juvenile specimens recorded. Historical data for the $1 / 16^{\text {th }}$ degree square grids (loci), in which each of the sampling sites of the current study was located, were extracted from the National Freshwater Snail Collection at the Unit for Environmental Sciences and Management, Potchefstroom Campus of the North-West University. During this study, 20 and 9 species were recovered from the Marico and Crocodile Rivers, respectively, as compared to 13 and 12 species on record for these loci, respectively. Juvenile specimens were present during the four surveys at most of the sites. Canonical correspondence analyses were applied which revealed that biotopes, water temperature and EC played the most significant role in the distribution and abundance of species. The relatively high mollusc diversity and the fact that juveniles were present throughout the study, demonstrated that current habitat and environmental conditions were suitable to promote recruitment and the sustainability of diverse mollusc populations in the Marico River and its tributaries. However, in contrast to this, the exploitation of and habitat transformation in the Crocodile River has resulted in the decrease of biotopes which eventually could have led to the decrease in diversity and the establishment of $P$. acuta, an exotic invader species.
\end{abstract}

Keywords: freshwater molluscs, biodiversity, Marico River, Crocodile River, environmental variables

\section{INTRODUCTION}

Freshwater molluscs are the second most diverse animal phylum on earth (Lydeard et al., 2004). However, they are poorly documented, extremely threatened and have the highest number of recorded extinctions of any major taxonomic group (Lydeard et al., 2004; Vaughn and Taylor, 1999). The decline in freshwater molluscs goes unnoticed due to poor documentation and monitoring, as only a fragment of molluscan species $(<2 \%)$ have had their conservation status accurately assessed (Lydeard et al., 2004; Reckendorfer et al., 2006).

Four hundred species of freshwater molluscs have been previously identified in Africa (Brown, 1994) and, according to De Kock and Wolmarans (1998), the distribution of these molluscs is primarily influenced by the availability of suitable aquatic biotopes. The association of different freshwater molluscs with specific biotopes, such as marginal and aquatic vegetation and sediment present at different water velocities and depths, is well known and documented (Brown, 1978; Brown, 1994; Dallas, 2007; Odume et al., 2015). These biotopes are under constant threat worldwide as a consequence of various anthropogenic impacts, geomorphological alterations and the changing availability of water (Wittmann, 1975; Vaughn and Taylor, 1999; Reckendorfer et al., 2006; Taylor et al. 2007; De Klerk et al., 2012; DWA, 2012).

\footnotetext{
* To whom all correspondence should be addressed.

e-mail: Hilde.kemp@nwu.ac.za

Received: 4 February 2015; accepted in revised form 9 March 2016
}

With regard to South Africa, nearly $71 \%$ of the main rivers are considered as either endangered or critically endangered as the result of exploitation (Nel et al., 2004). The Crocodile River, which is characterised by sprawling urbanization and industrialization in the region of northern Johannesburg and Pretoria, is also under severe threat of pollution due to extensive agricultural activities, the sporadic release of water from impoundments such as the Hartbeespoort Dam, and large mining developments north of the Magaliesberg (Wittmann, 1975; Taylor et al., 2007; De Klerk et al., 2012; DWA, 2012). All of these stressors could have a detrimental effect on the aquatic ecosystems and biotope availability. In contrast, the general state of the Marico River is considered to be 'natural' to 'good', free of significant organic pollution, with a pronounced biodiversity and overall good water quality (RHP, 2005). However, the water quality of two of its major tributaries, namely, the Klein Marico River and the Sterkstroom, is defined as 'fair' to 'poor' (RHP, 2005).

Although mollusc surveys have previously been done in the Marico and Crocodile River catchment areas, (National Freshwater Snail Collection Database, North-West University, Potchefstroom Campus), limited information regarding diversity has previously been published. Furthermore, in view of the fact that the Marico River is still considered to be relatively pristine, while the Crocodile River has been subjected to ongoing exploitation and habitat transformation, it is of great importance to survey these areas in order to establish the current status of the mollusc diversity for conservation purposes. 


\section{Study area}

The Marico River stretches from its source, the Marico Eye near Swartruggens, for $250 \mathrm{~km}$ until its confluence with the Crocodile River to form the Limpopo River. The Crocodile River, originating at Roodepoort, meanders via Hartbeespoort Dam past Thabazimbi to the Botswana border where it joins the Marico River. Nine sites in the Marico River and seven sites in the Crocodile River catchments were selected for sampling. Site selection was influenced by logistical accessibility to the rivers, availability of water and suitable biotopes (Dickens and Graham, 2002; Gerber and Gabriel, 2002; Dallas, 2007). Locations of these sites are depicted in Fig. 1 while site descriptions and aquatic biotopes are displayed in Table 1.

\section{Sampling equipment and techniques}

Four surveys were conducted, two in an early (May 2013 and 2014) and two in a late (November 2013 and 2014) low-flow period. The coordinates of each sampling site were determined with a Garmin Nuvi 500 GPS.

Semi-quantitative surveys were done by sampling the vegetation, as well as the substratum, with a standard SASS net (Dickens and Graham, 2002) for approximately 15 min each. Molluscs were collected along the margins of the rivers up to a depth of 70 $\mathrm{cm}$. Aquatic vegetation and marginal vegetation were sampled by pushing the net vigorously into the vegetation and moving it backwards and forwards through the same area. Substrata of biotopes consisting mainly of mud, sand, gravel or stones were sampled by shuffling the feet whilst continuously sweeping the net

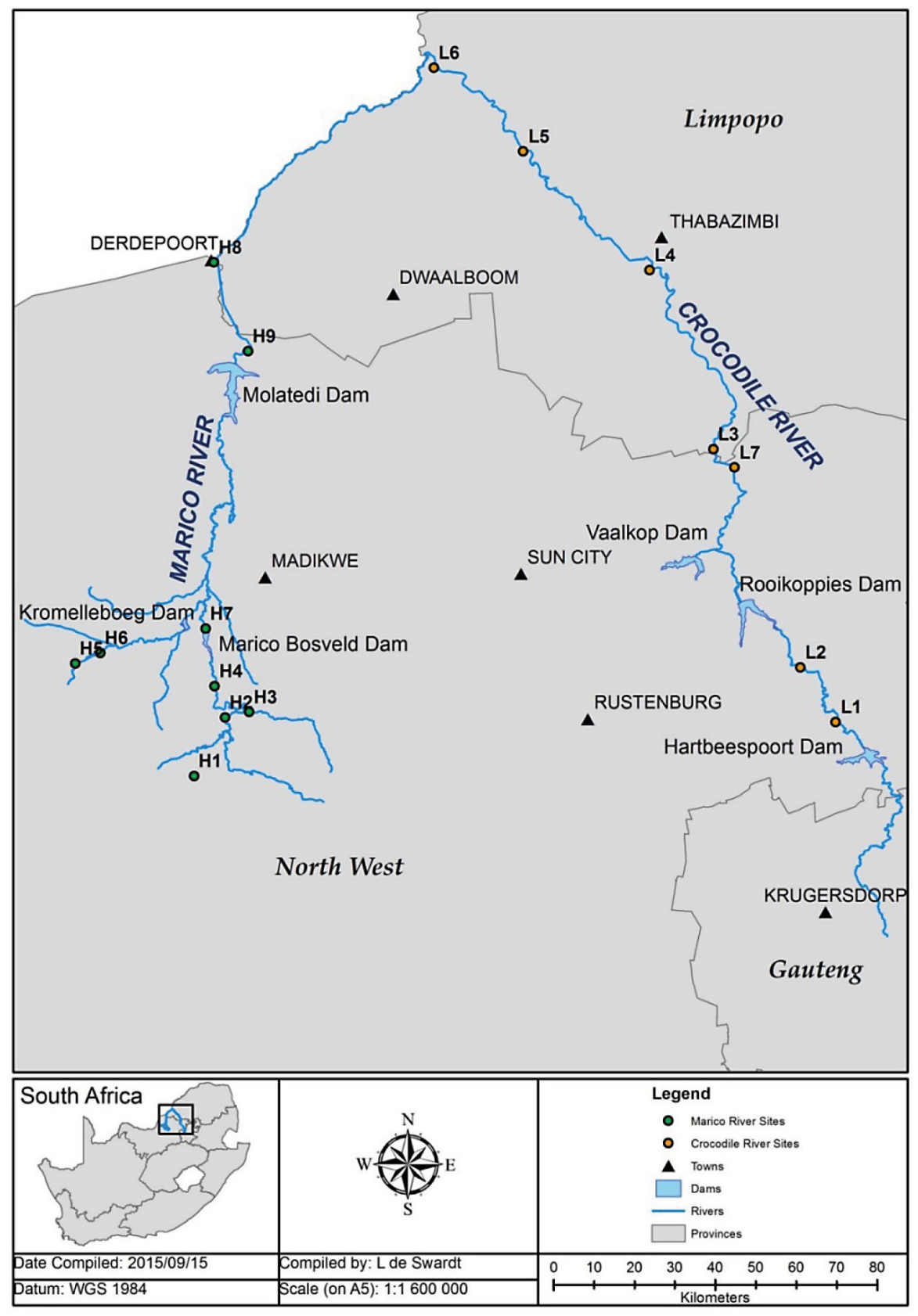

Figure 1

Map of the study area 


\begin{tabular}{|c|c|c|}
\hline \multicolumn{3}{|c|}{$\begin{array}{c}\text { TABLE } 1 \\
\text { Site location, river name and aquatic biotopes present at each site }\end{array}$} \\
\hline $\begin{array}{l}\text { Site, coordinates } \\
\text { and altitude }\end{array}$ & River & $\begin{array}{l}\text { Aquatic biotopes } \\
\text { (according to Gerber and Gabriel, 2002) }\end{array}$ \\
\hline \multicolumn{3}{|l|}{ Marico River } \\
\hline $\begin{array}{l}\text { Site H1 } \\
\text { S } 25^{\circ} 47^{\prime} 32.1 \\
\text { E } 26^{\circ} 21^{\prime} 54.1 \\
1480 \mathrm{~m} \\
\end{array}$ & Marico Eye, source of Marico River & $\begin{array}{l}\text { Abundant marginal and aquatic vegetation, pool and } \\
\text { backwaters with stones }\end{array}$ \\
\hline $\begin{array}{l}\text { Site H2 } \\
\text { S } 25^{\circ} 39^{\prime} 45.1 \\
\text { E } 26^{\circ} 26^{\prime} 01.9 \\
1197 \mathrm{~m}\end{array}$ & $\begin{array}{l}\text { Marico River before its confluence with Sterkstroom, } \\
20 \mathrm{~km} \text { downstream of the Eye }\end{array}$ & $\begin{array}{l}\text { Little to no marginal vegetation, stones in current, } \\
\text { stones out of current, riffle, run and pool. }\end{array}$ \\
\hline $\begin{array}{l}\text { Site H3 } \\
\text { S } 25^{\circ} 39^{\prime} 00.6 \\
\text { E } 26^{\circ} 29^{\prime} 16.3 \\
1170 \mathrm{~m}\end{array}$ & $\begin{array}{l}\text { Sterkstroom } 5 \mathrm{~km} \text { before its confluence with Marico } \\
\text { River }\end{array}$ & $\begin{array}{l}\text { Little to no vegetation, bedrock, stones in current, riffle, } \\
\text { run and pool }\end{array}$ \\
\hline $\begin{array}{l}\text { Site H4 } \\
\text { S } 25^{\circ} 35^{\prime} 33.4 \\
\text { E } 26^{\circ} 24^{\prime} 39.4 \\
1077 \mathrm{~m} \\
\end{array}$ & $\begin{array}{l}\text { Marico River } 10 \mathrm{~km} \text { above Marico-Bosveld Dam, after } \\
\text { its confluence with Sterkstroom }\end{array}$ & $\begin{array}{l}\text { Muddy and sandy substratum, filamentous algae, } \\
\text { abundant marginal and aquatic vegetation, stones in } \\
\text { current, stones out of current, riffle, run and pool }\end{array}$ \\
\hline $\begin{array}{l}\text { Site H5 } \\
\text { S } 25^{\circ} 32^{\prime} 31.4 \\
\text { E } 26^{\circ} 06^{\prime} 17.3 \\
1150 \mathrm{~m}\end{array}$ & $\begin{array}{l}\text { Klein Marico River } 5 \mathrm{~km} \text { above Klein-Maricopoort } \\
\text { (Bospoort) Dam }\end{array}$ & $\begin{array}{l}\text { Little to no marginal and aquatic vegetation, filamen- } \\
\text { tous algae, muddy substratum, riffle and run }\end{array}$ \\
\hline $\begin{array}{l}\text { Site H6 } \\
\text { S } 25^{\circ} 31^{\prime} 09.2 \\
\mathrm{E} 26^{\circ} 09^{\prime} 25.1 \\
1135 \mathrm{~m}\end{array}$ & $\begin{array}{l}\text { Klein Marico River } 1 \mathrm{~km} \text { below Klein-Maricopoort } \\
\text { (Bospoort) Dam }\end{array}$ & $\begin{array}{l}\text { Little to no marginal and aquatic vegetation, pool with } \\
\text { muddy substratum stones in current, riffle and run }\end{array}$ \\
\hline $\begin{array}{l}\text { Site H7 } \\
\text { S } 25^{\circ} 27^{\prime} 52.6 \\
\text { E } 26^{\circ} 23^{\prime} 26.9 \\
1037 \mathrm{~m}\end{array}$ & Marico River directly below Marico-Bosveld Dam & $\begin{array}{l}\text { Marginal and aquatic vegetation, filamentous algae and } \\
\text { bedrock }\end{array}$ \\
\hline $\begin{array}{l}\text { Site H8 } \\
\text { S } 24^{\circ} 39^{\prime} 15.9 \\
\text { E } 26^{\circ} 24^{\prime} 28.7 \\
914 \mathrm{~m}\end{array}$ & Marico River at Derdepoort & $\begin{array}{l}\text { Abundant marginal and aquatic vegetation, backwater } \\
\text { with muddy and sandy substratum, filamentous algae }\end{array}$ \\
\hline $\begin{array}{l}\text { Site H9 } \\
\text { S } 24^{\circ} 50^{\prime} 54.2 \\
\text { E } 26^{\circ} 29^{\prime} 07.1 \\
926 \mathrm{~m}\end{array}$ & Marico River $2 \mathrm{~km}$ below Molatedi Dam & $\begin{array}{l}\text { Run with muddy substratum, bedrock, stones in cur- } \\
\text { rent, stones out of current, riffle and pool }\end{array}$ \\
\hline \multicolumn{3}{|l|}{ Crocodile River } \\
\hline $\begin{array}{l}\text { Site L1 } \\
\text { S } 25^{\circ} 40^{\prime} 22.1 \\
\text { E } 27^{\circ} 47^{\prime} 25 \\
1104 \mathrm{~m}\end{array}$ & Crocodile River at Brits & $\begin{array}{l}\text { Marginal and aquatic vegetation, filamentous algae, rif- } \\
\text { fle and run with sand and bedrock substratum, stones } \\
\text { in current }\end{array}$ \\
\hline $\begin{array}{l}\text { Site L2 } \\
\text { S } 25^{\circ} 33^{\prime} 02.9 \\
\text { E } 27^{\circ} 42^{\prime} 40.9 \\
1055 \mathrm{~m}\end{array}$ & Crocodile River downstream of Brits & $\begin{array}{l}\text { Run and pool with sand substratum and filamentous } \\
\text { algae }\end{array}$ \\
\hline $\begin{array}{l}\text { Site L3 } \\
\text { S } 25^{\circ} 03^{\prime} 59.6 \\
\text { E } 27^{\circ} 31^{\prime} 06.2 \\
936 \mathrm{~m}\end{array}$ & Crocodile River at Koedoeskop Bridge & $\begin{array}{l}\text { Run and pool with muddy substratum and filamentous } \\
\text { algae }\end{array}$ \\
\hline $\begin{array}{l}\text { Site L4 } \\
\text { S } 24^{\circ} 40^{\prime} 05.8 \\
\text { E } 27^{\circ} 22^{\prime} 35.2 \\
904 \mathrm{~m}\end{array}$ & Crocodile River at Thabazimbi & $\begin{array}{l}\text { Run and pool with sand substratum and filamentous } \\
\text { algae }\end{array}$ \\
\hline $\begin{array}{l}\text { Site L5 } \\
\text { S } 24^{\circ} 24^{\prime} 16.8 \\
\text { E } 27^{\circ} 05^{\prime} 46.7 \\
905 \mathrm{~m}\end{array}$ & Crocodile River downstream of Thabazimbi & Run and pool, sand substratum and filamentous algae \\
\hline $\begin{array}{l}\text { Site L6 } \\
\text { S } 24^{\circ} 13^{\prime} 07 \\
\text { E } 26^{\circ} 53^{\prime} 51.6 \\
836 \mathrm{~m}\end{array}$ & Crocodile River at Rooibokkraal & $\begin{array}{l}\text { Run and pool with sand substratum, sparse marginal } \\
\text { and aquatic vegetation, filamentous algae }\end{array}$ \\
\hline $\begin{array}{l}\text { Site L } \\
\text { S } 25^{\circ} 06^{\prime} 24.7 \\
\text { E } 27^{\circ} 33^{\prime} 55.2 \\
956 \mathrm{~m}\end{array}$ & Pienaars River & $\begin{array}{l}\text { Run and pool with mud and clay substratum, stones in } \\
\text { current }\end{array}$ \\
\hline
\end{tabular}


over the disturbed area. Contents of the net were then transferred to a rectangular plastic container $(360 \times 470 \times 80 \mathrm{~mm})$ which was filled with water from the habitat to a level of approximately 40 $\mathrm{mm}$. Most of the debris was then carefully removed by hand and scrutinised for specimens that might still be attached. Thereafter the contents of the container were decanted into a cone-shaped Perlon gauze net $(0.25 \mathrm{~mm}$ mesh) suspended on a stand. The content of the net was transferred to a plastic container with a tight-fitting lid and $90 \%$ ethanol was added to preserve the samples. The container was then labelled with relevant site information. The samples were transported to the laboratory where each sample was decanted into a rectangular Perspex sorting tray $(300 \times 200 \times 25 \mathrm{~mm})$ with a transparent bottom provided with a $10 \mathrm{~mm}$ square grid. All molluscs were subsequently removed under a stereomicroscope mounted on a sliding stand and identified up to species level (Walker, 1923; Connolly, 1939; Brown, 1994; Appleton, 2002). To obtain an indication of recruitment, the presence of juvenile specimens was also recorded.

\section{Historical data}

Historical data (1958 to 1984 ), for the $1 / 16^{\text {th }}$ degree square grids (loci) in which each of the sampling sites of the current study was located, were extracted from the National Freshwater Snail Collection (NFSC). These data represent species collected in both lotic and lentic waterbodies.

\section{Environmental parameters}

Electrical conductivity, $\mathrm{pH}$ and water temperature were measured in situ at all sites during each survey using a portable digital thermometer (Checktemp, Hanna Instruments), portable digital conductivity meter (DIST 3, HI 98303, Hanna Instruments) and portable digital $\mathrm{pH}$ probe (HI 98128, Hanna Instruments).

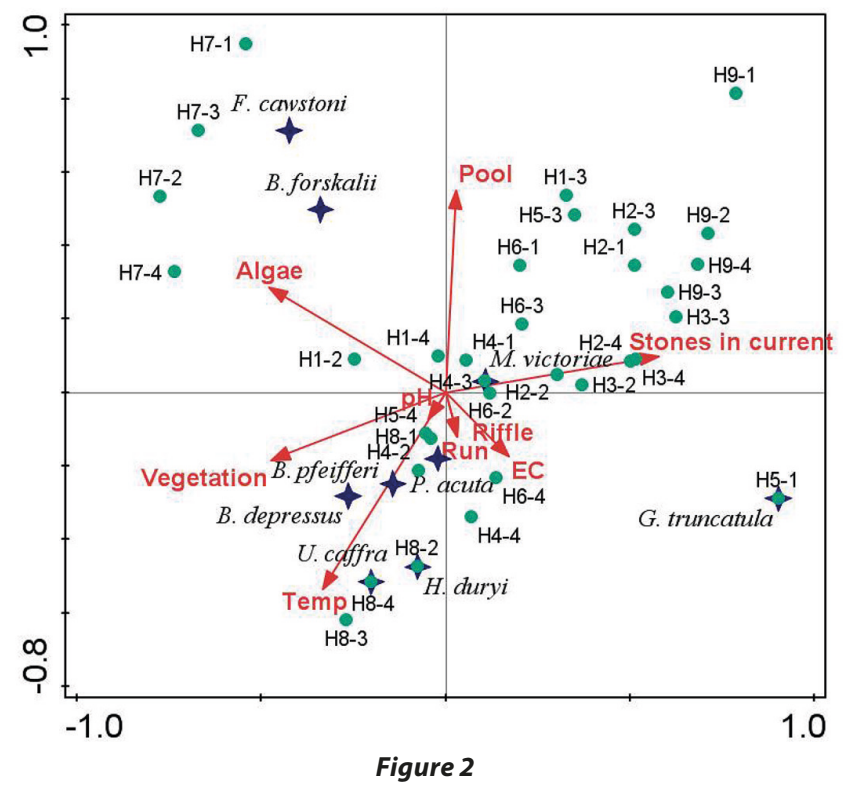

CCA tri-plot illustrating associations between species (blue stars), sampling sites in the Marico River during 4 surveys (green dots), environmental variables (red arrows; electrical conductivity $(E C)$, water temperature and $\mathrm{pH}$ ) and biotope availability ( $\mathrm{pool}$, riffle, run, stones in current, vegetation and the presence of algae). Only taxa for which more than $10 \%$ of the variation is explained by the model are depicted. The tri-plot describes $57.26 \%$ of the total variation, with $38.52 \%$ being described on the first axis and $18.74 \%$ on the second axis.

\section{Statistical analyses}

Canonical correspondence analyses (CCAs) were conducted using CANOCO 5 software, to investigate the distribution and abundance of mollusc species between sites and surveys in relation to the influence of selected environmental variables (water temperature, $\mathrm{pH}$, electrical conductivity (EC) and biotope availability).

\section{RESULTS}

The location of each site is depicted in Fig. 1 and site coordinates, river names and biotopes present at each site are given in Table 1. Mollusc diversity, abundance and species richness (SR), and selected environmental parameters for each of the four surveys, are displayed in Tables 2 and 3. The molluscs on record in the NFSC database which were previously collected from the same loci (not necessarily from the same sites), as well as those species recovered during the present study, are presented in Table 4. Canonical correspondence analyses (CCAs), illustrating associations between species, sampling sites during four surveys, environmental variables and biotope availability, are depicted in Figs 2 and 3.

A total number of 20 species were recovered from the Marico River and tributaries (Table 2). The highest species diversity in the Marico River ( $\mathrm{SR}=12$ ) was recorded for both Sites $\mathrm{H} 4$ and $\mathrm{H} 8$, while the highest total number of species per survey (9) was also found at these two sites (Table 2). The most common and abundant species were Burnupia trapezoidea, Lymnaea natalensis and Pisidium langleyanum (Table 2). The lowest species richness was found at Sites $\mathrm{H} 5$ and $\mathrm{H} 9$, with a total number of 4 and 2 species, respectively. Only one specimen of Galba truncatula, Helisoma duryi and Unio caffra was found during the study. Seven species not previously on record for this area were recorded during the present study. However, Bulinus tropicus, which was previously recorded in the area (Table 4), was not found. Water temperature and $\mathrm{pH}$ did not vary considerably between sites, but seasonal fluctuation in temperature between surveys was observed (Table 2). Electrical

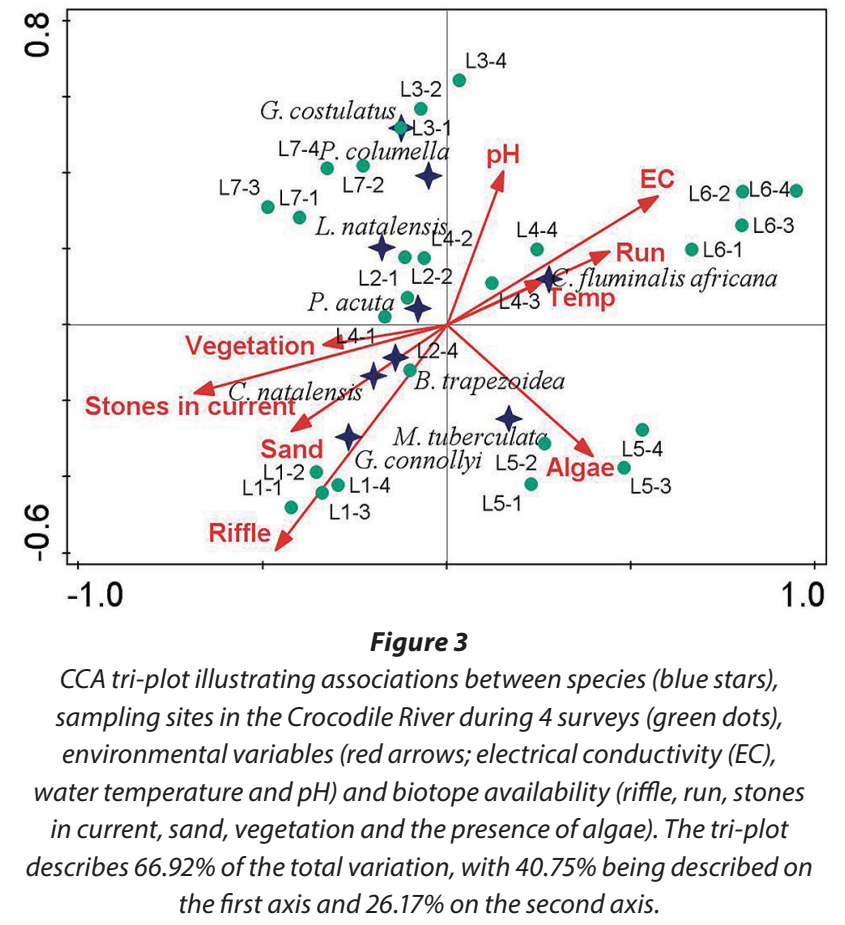



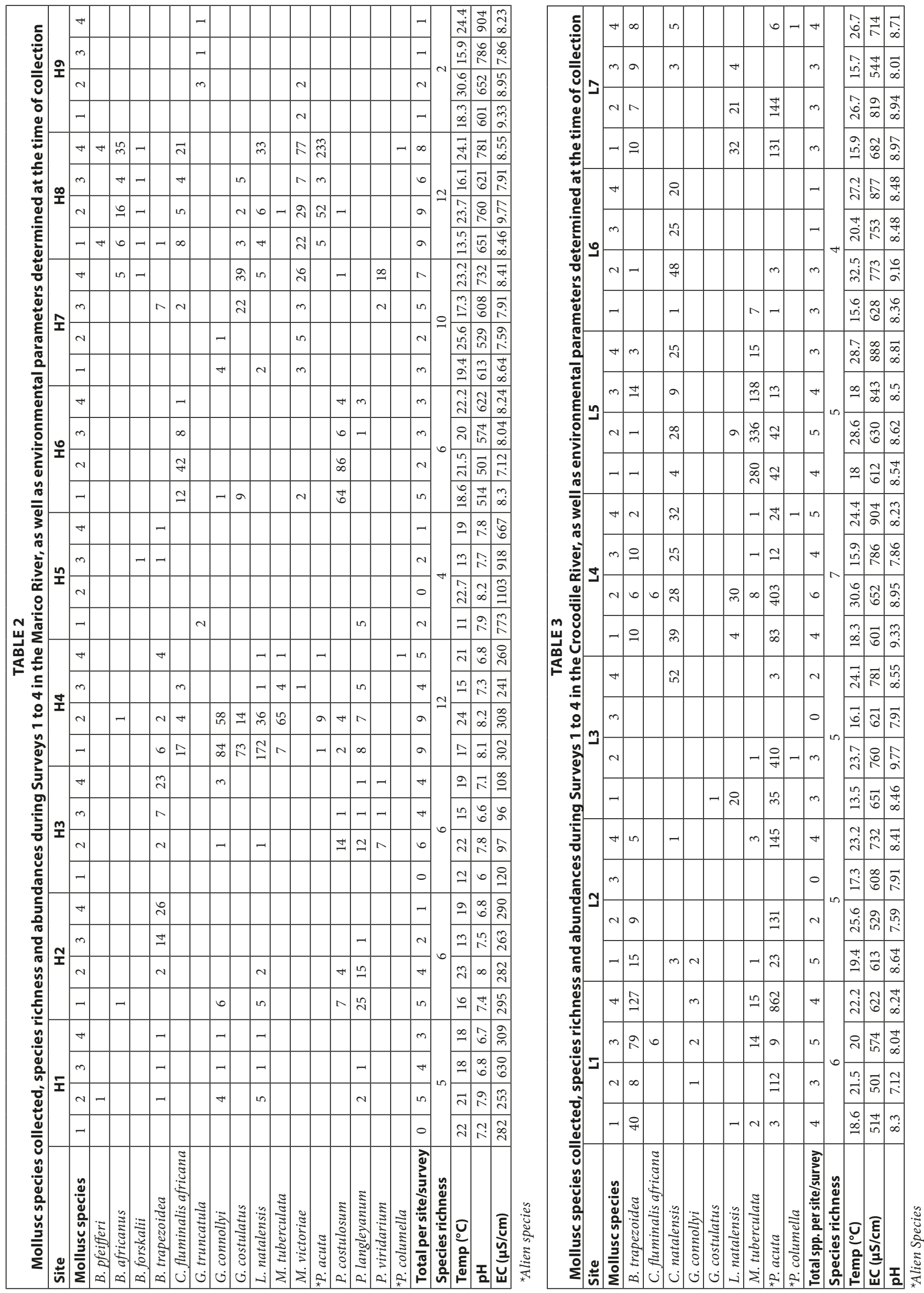

http://dx.doi.org/10.4314/wsa.v42i2.09 


\begin{tabular}{|c|c|c|c|c|}
\hline \multicolumn{5}{|c|}{$\begin{array}{c}\text { Table } 4 \\
\text { Mollusc species on record in the National Freshwater Snail } \\
\text { Collection (NFSC) from } 1958 \text { to } 1984 \text { and species collected } \\
\text { during the } 2013 \text { and } 2014 \text { study }\end{array}$} \\
\hline \multirow{2}{*}{$\begin{array}{l}\text { Mollusc } \\
\text { species }\end{array}$} & \multicolumn{2}{|c|}{$\begin{array}{l}\text { Marico River and } \\
\text { Catchment }\end{array}$} & \multicolumn{2}{|c|}{$\begin{array}{l}\text { Crocodile River and } \\
\text { Catchment }\end{array}$} \\
\hline & 1958-1984 & 2013-2014 & 1958-1984 & 2013-2014 \\
\hline B. pfeifferi & $x$ & $x$ & $x$ & \\
\hline B. africanus & $x$ & $x$ & $x$ & \\
\hline B. depressus & $x$ & $x$ & $x$ & \\
\hline B. forskalii & $x$ & $x$ & $x$ & \\
\hline B. tropicus & $x$ & & $x$ & \\
\hline B. trapezoidea & $x$ & $x$ & $x$ & $x$ \\
\hline C. natalensis & & & & $x$ \\
\hline $\begin{array}{l}\text { C. fluminalis } \\
\text { africana }\end{array}$ & $x$ & $x$ & $x$ & $x$ \\
\hline F. cawstoni & & $x$ & & \\
\hline G. truncatula & & $x$ & & \\
\hline G. costulatus & $x$ & $x$ & $x$ & $x$ \\
\hline G. connollyi & $x$ & $x$ & & $x$ \\
\hline${ }^{\star} H$. duryi & & $x$ & & \\
\hline L. natalensis & $x$ & $x$ & $x$ & $x$ \\
\hline M. tuberculata & $x$ & $x$ & $x$ & $x$ \\
\hline M. victoriae & & $x$ & & \\
\hline${ }^{*} P$. acuta & & $x$ & $x$ & $x$ \\
\hline P. costulosum & & $x$ & & \\
\hline P. langleyanum & & $x$ & & \\
\hline P. viridarium & & $x$ & & \\
\hline${ }^{*}$. columella & $x$ & $x$ & $x$ & $x$ \\
\hline U. caffra & $x$ & $x$ & & \\
\hline
\end{tabular}

The length of the arrows in the CCA tri-plot (Fig. 3) indicates that EC, algae, riffle and stones in current biotopes played a significant role on the occurrence and distribution of species, while $\mathrm{pH}$, run and sand biotopes had a lesser, and temperature and vegetation an even smaller, influence. An association can be seen between C. fluminalis africana, Site L6 and EC. Melanoides tuberculata associated with Site L5 and the presence of algae, while G. connollyi associated with Site L1 and a riffle biotope.

\section{DISCUSSION}

From historical data in the database of the NFSC it is clear that the Marico and Crocodile River areas had a similar molluscan diversity, with only one more species recorded from the Marico River than the Crocodile (Table 4). The results of the current study, however, show a dramatic change in this similarity. The number of species found in the Marico River area increased from 13 to 20 species, while the number of species in the Crocodile River area decreased from 12 to 9 species.

Of the 13 species on record for the Marico River area, only B. tropicus was not recovered during the present study, probably due to the fact that this snail is primarily found in lentic waterbodies such as dams and lakes and various ephemeral habitats, which were included in the previous surveys (De Kock et al., 2002). Of the 12 species on record for the Crocodile River area, only 7 were collected during this study, while 2 species, C. natalensis and G. connollyi were recorded for the first time. Of the 21 species recovered during this study, only 7 were found in both the Marico and Crocodile Rivers. Of these 7 species 6 can be considered as generalists which are able to utilise both sediment and vegetation biotopes, while the $7^{\text {th }}$ species, C. fluminalis africana, is a bottom dweller and not dependent on vegetation biotopes (De Kock and Wolmarans, 2007a).

The importance of the effect of biotope availability on biodiversity (Dallas, 2007) is supported by the high species richness $(\mathrm{SR}=12)$ found at Sites H4 and H8 in the Marico River, where a large selection of biotopes was present (Table 1). The low species richness $(\mathrm{SR}=2)$ found at Site H9 was possibly due to the fact that this site was situated directly downstream from the Molatedi Dam where the constant release of large volumes of water every 4 to 6 weeks (RHP, 2005) possibly resulted in gross disturbance and transformation of the aquatic biotopes, as reflected in the absence of marginal and aquatic vegetation (Table 1). Furthermore, this site was also negatively impacted by the clearing of riparian vegetation and grazing by cattle from a nearby informal settlement, as observed during the surveys. With regard to Site H5, located close to Zeerust, the low mollusc diversity $(\mathrm{SR}=4)$ could be ascribed to the lack of suitable biotopes and possible negative impacts from the nearby industrial and urban activities (RHP, 2005), as obvious signs of littering and eutrophication were observed. The fact that B. trapezoidea, L. natalensis and P. langleyanum were the most commonly occurring species in the Marico River and tributaries, could be attributed to their wide distribution in the area, as previously recorded (NFSC database; De Kock et al., 2001; De Kock and Wolmarans, 2008). The single specimen of M. victoriae collected at Site $\mathrm{H} 4$ was unexpected, as this locality is well beyond the distribution range previously reported by De Kock and Wolmarans (2009).

The ordination in the CCA tri-plot (Fig. 2) shows that, regarding the environmental variables, $\mathrm{pH}$ and $\mathrm{EC}$ did not play a significant role in species occurrence and distribution, but water temperature and the presence or absence of different 
biotopes did play a significant role. The fact that water temperature played such a significant role in the distribution of mollusc species, is in accordance with the results of similar studies in Africa (Tchakonte et al., 2014; Abd El-Wakeil et al., 2015). Water temperature is further considered as one of the major factors influencing reproduction of molluscs (De Kock and Van Eeden, 1982). However, the lower temperature during the May surveys and the higher temperature during the November surveys did not prevent recruitment, as juvenile specimens of different generations of the majority of species were present at most of the sampling sites.

The association of G. truncatula with Site $\mathrm{H} 5$ and $H$. duryi and U. caffra with Site H8, is most probably due to the fact that these species were found only once and in single numbers at these sites.

A comparison between the historical data and the results of the current study is not really feasible as the historic data have been collected by many different people over several decades. However, it is still clear that a higher diversity is currently found in the Marico River, possibly due to the fact that previous surveys did not concentrate on the Marico River per se, as well as the fact that this river has not been seriously impacted by anthropogenic activities over the past three decades (RHP, 2005).

Of the 9 species found in the Crocodile River, the occurrence of several of these, namely C. fluminalis africana, B. trapezoidea, G. costulatus, G. connollyi and C. natalensis, could be expected, as they are widely distributed in South Africa (Database of the NFSC; De Kock and Wolmarans, 2004; 2006; 2007a; b) and predominantly associate with sediment biotopes that were available at almost all of the sites. However, the limited availability of marginal and aquatic vegetation at most of the sites did not prevent the occurrence of $P$. acuta, L. natalensis and P. columella, which are generalists in respect of their biotope preferences (De Kock et al., 1989; Brown, 1994; De Kock et al., 2001). As in the case of the Marico River, the ordination in the CCA tri-plot (Fig. 3) shows that biotope availability played a significant role in species occurrence and distribution. In the Crocodile River, however, EC was also an important factor in this respect and these results are in agreement with the conclusions of Tchakonte et al. (2014) and Abd El-Wakeil et al. (2015). The presence of filamentous algae, an indication of organic enrichment, and the considerably higher recorded EC values at most of the sites throughout the study, could be attributed to the anthropogenic stressors mentioned above.

Three alien species, namely $H$. duryi, P. acuta, and $P$. columella, were found during this study. Of these, P. columella is on record as the third most widespread freshwater snail species in South Africa (De Kock and Wolmarans, 2008). However, during this study it was found only in a few sites and also in limited numbers in both the Marico River (Sites H4 and H7) and the Crocodile River (Sites L3, L4 and L7). The fact that $P$. acuta was found at all the sites in the Crocodile River, often in high numbers, is not surprising as it has attributes such as a superior fecundity rate, as reported by Appleton and Brackenbury (1998), and the ability to migrate upstream (Appleton and Branch, 1989). Furthermore, this species can serve as an indicator of organic-enriched water, commonly occurs in areas where sewage pollution is obvious and, according to Brown (1994), seems to be closely associated with human activities. Helisoma duryi, of which only one specimen was found at Site H8, is widespread in artificial waterbodies but not invasive (Appleton, 2003). Of the 41 records of this species in the NFSC database reported by De
Kock and Joubert (1991), only 15 were from natural habitats.

The relatively high mollusc diversity, and the fact that juveniles were present throughout the study, demonstrated that current habitat and environmental conditions were suitable to promote recruitment and the sustainability of diverse mollusc populations in the Marico River and its tributaries. However, in contrast to this, the exploitation of and habitat transformation in the Crocodile River resulted in the decrease of biotopes which eventually could have led to the decrease in diversity and the establishment of P. acuta, an exotic invader species.

\section{ACKNOWLEDGMENTS}

We are grateful to the Unit for Environmental Sciences and Management, North-West University, Potchefstroom, South Africa for financial support and infrastructure. Our sincere thanks and appreciation are hereby given to Ms Liesl de Swart for the detailed map the study area.

\section{REFERENCES}

ABD EL-WAKEIL KF, OBUID-ALLAH AH, MOHAMED AH and ABD EL-AZIZ FE-ZA (2015) A comparison of molluscan communities in a section of the Nile River at Assiut. Egypt, with different chemical and thermal pollution. Mollusc. Res. 35 73-80. http:// dx.doi.org/10.1080/13235818.2014.919693

APPLETON CC (2002) Mollusca. In: Day JA, and De Moor IJ (eds) Guides to the Freshwater Invertebrates of Southern Africa, Araneae, Water Mites and Mollusca. WRC Report No. TT 182/02. Water Research Commission, Pretoria. 42-125.

APPLETON CC (2003) Alien and invasive fresh water Gastropoda in South Africa. Afr. J. Aquat. Sci. 28 69-81. http://dx.doi.org/10.2989/ 16085914.2003.9626602

APPLETON CC and BRACKENBURY TD (1998) Introduced freshwater gastropods in Africa with special reference to Physa acuta. In: Madsen H, Appleton CC and Chimbari M (eds) Proc. Workshop on Medical Malacology in Africa. September 1997, Harare, Zimbabwe. Danish Bilharziasis Laboratory, Danida, Denmark. 22-26.

APPLETON CC and BRANCH GM (1989) Upstream migration by the invasive snail Physa acuta in Cape Town, South Africa. S. Afr. J. Sci. 85 189-190.

BROWN DS (1978) Freshwater molluscs. In: Werger M J A (ed.) Biogeography and Ecology of Southern Africa. W Junk, The Hague. 1155-1180. http://dx.doi.org/10.1007/978-94-009-9951-0_35

BROWN DS (1994) Freshwater Snails of Africa and their Medical Importance (revised $2^{\text {nd }}$ edn). Taylor \& Francis, London.

CONNOLLY M (1939) A monographic survey of the South African non-marine Mollusca. Ann. S. Afr. Mus. 33 1-660.

DALLAS HF (2007) The influence of biotope availability on macroinvertebrate assemblages in South African Rivers: implications for aquatic bioassessment. Freshwater Biol. 52 370-380. http://dx.doi. org/10.1111/j.1365-2427.2006.01684.x

DE KLERK AR, DE KLERK LP, CHAMIER J and WEPENER V (2012) Seasonal variations of water and sediment quality parameters in endorheic reed pans on the Mpumalanga Highveld. Water SA 38 663-672. http://dx.doi.org/10.4314/wsa.v38i5.3

DE KOCK KN and JOUBERT PH (1991) Life-table experiments with Helisoma duryi (Wetherby) and Biomphalaria pfeifferi (Krauss) at constant temperatures. S. Afr. J. Zool. 26 149-152. http://dx.doi.org/ 10.1080/02541858.1991.11448243

DE KOCK KN, JOUBERT PH and PRETORIUS SJ (1989) Geographical distribution and habitat preferences of the invader freshwater snail species Lymnaea columella (Mollusca: Gastropoda) in South Africa. Onderstepoort J. Vet. Res. 56 271-275.

DE KOCK KN and VAN EEDEN JA (1982) Life-table studies on freshwater snails. The effect of constant temperature on the population dynamics of Biomphalaria pfeifferi (Krauss). Wetenskaplike Bydraes van die PU vir CHO, Reeks B: Natuurwetenskappe 107 1-17. 
DE KOCK KN and WOLMARANS CT (1998) A re-evaluation of the occurrence of freshwater molluscs in the Kruger National Park. Koedoe 51 1-8. http://dx.doi.org/10.4102/koedoe.v41i1.240

DE KOCK KN and WOLMARANS CT (2004) Verspreiding en habitats van Gyraulus connollyi, slaktussengasheer van ingewandsbotte van die familie Echinostomatidae, in Suid-Afrika. Suid-Afr. Tyds. Natuurwet. Tegnol. 23 79-86.

DE KOCK KN and WOLMARANS CT (2006) Verspreiding en habitats van Gyraulus costulatus, potensiële slaktussengasheer van ingewandsbotte van die familie Echinostomatidae, in Suid-Afrika. Suid-Afr. Tyds. Natuurwet. Tegnol. 25 19-32.

DE KOCK KN and WOLMARANS CT (2007a) Distribution and habitats of Corbicula fluminalis africana (Mollusca: Bivalvia) in South Africa. Water SA 33 711-717.

DE KOCK KN and WOLMARANS CT (2007b) Verspreiding en habitats van Ceratophallus natalensis (Mollusca:Planorbinae) in Suid-Afrika. Suid-Afr. Tyds. Natuurwet. Tegnol. 26 109-120. http:// dx.doi.org/10.4314/wsa.v35i5.49197

DE KOCK KN and WOLMARANS CT (2008) Distribution of the pill clam Pisidium langleyanum Melvill \& Ponsonby, 1891 (Bivalvia: Sphaeriidae) in South Africa. Water SA 34 623-630.

DE KOCK KN and WOLMARANS CT (2009) Distribution and habitats of Melanoides tuberculata (Müller, 1774) and M. victoriae (Dohrn, 1865) (Mollusca: Prosobranchia: Thiaridae) in South Africa. Water SA 35 713-720.

DE KOCK KN, WOLMARANS CT, BORNMAN M and MAREE DC (2002) Verspreiding en habitats van Bulinus tropicus, tussengasheerslak van die peervormige bot Calicophoron microbothrium, in Suid-Afrika. Suid-Afr. Tyds. Natuurwet. Tegnol. 14 12-16.

DE KOCK KN, WOLMARANS CT, STRAUSS HD and KILLIAN M (2001) Verspreiding en habitats van Lymnaea natalensis, tussengasheerslak van die lewerbot Fasciola gigantica, in Suid-Afrika. Suid-Afr. Tyds. Natuurwet. Tegnol. 20 49-53.

DWA (DEPARTMENT OF WATER AFFAIRS, SOUTH AFRICA) (2012) Crocodile West River Reconciliation Strategy 2012: Support to the implementation and maintenance of the reconciliation strategy of the Crocodile West Water Supply System. DWA Report number: P WMA 03/A31/00/6110/4. Department of Water Affairs, Pretoria.

DICKENS CWS and GRAHAM PM (2002) The South African Scoring System (SASS) Version 5 Rapid Bioassessment Method for Rivers. Afr. J. Aquat. Sci. 27 1-10. http://dx.doi.org/10.2989/16085914.200 2.9626569

GERBER A and GABRIEL MJM (2002a) Aquatic Invertebrates of South African Rivers, Field Guide (1st edn.). Institute for Water Quality
Studies, Department of Water Affairs and Forestry (DWAF), Pretoria. $150 \mathrm{pp}$.

LYDEARD C, COWIE RH, PONDER WF, BOGAN AE, BOUCHET P, CLARK SA, CUMMINGS KS., FREST TJ, GARGOMINY O, HERBERT DG and co-authors (2004) The global decline of nonmarine mollusks, BioScience 54 321-330. http://dx.doi. org/10.1641/0006-3568(2004)054[0321:TGDONM]2.0.CO;2

ODUME ON, PALMER CG, ARIMORO FO and MENSAH PK (2015) Influence of selected biotopes on chironomid-based bioassessment of the Swartkops River, Eastern Cape, South Africa. Water SA 41 343-358. http://dx.doi.org/10.4314/wsa.v41i3.06

NEL J (2011) Atlas of Freshwater Ecosystem Priority Areas in South Africa, CSIR Impact Series. URL: http://www.csir.co.za/impact/docs/ Final_Freshwater_Atlas_Article.pdf (Accessed 4 September 2014).

NEL J, MAREE G, ROUX D, MOOLMAN J, KLEYNHANS N, SILBERBAUER M and DRIVER A (2004) South African National Spatial Biodiversity Assessment 2004: Technical Report. Volume 2 : River Component. CSIR Report No. ENV-S-I-2004-063. Council for Scientific and Industrial Research, Stellenbosch.

RECKENDORFER W, BARANYI C, FUNK A and SCHIEMER $\mathrm{F}$ (2006) Floodplain restoration by reinforcing hydrological connectivity: expected effects on aquatic mollusc communities. J. Appl. Ecol. 43 474- 484. http://dx.doi. org/10.1111/j.1365-2664.2006.01155.x

RHP (RIVER HEALTH PROGRAMME) (2005) State-of-Rivers Report: Monitoring and Managing the Ecological State of Rivers in the Crocodile (West) Marico Water Management Area. Department of Environmental Affairs and Tourism, Pretoria.

TAYLOR JC, PRYGIEL J, VOSLOO A, DE LA REY PA and RENSBURG L (2007) Can diatom-based pollution indices be used for biomonitoring in South Africa? A case study of the Crocodile West and Marico water management area. Hydrobiologia 592455 464. http://dx.doi.org/10.1007/s10750-007-0788-1

TCHAKONTÉ S, AJEAGAH GA, DIOMANDÉ D, CAMARA AI and NGASSAM P (2014) Diversity, dynamic and ecology of freshwater snails related to environmental factors in urban and suburban streams in Douala-Cameroon (Central Africa). Aquat. Ecol. 48 379-395. http://dx.doi.org/10.1007/s10452-014-9491-2

VAUGHN CC and TAYLOR CM (1999) Impoundments and the decline of freshwater mussels: a case study of an extinction gradient. Conserv. Biol. 13 912-920. http://dx.doi. org/10.1046/j.1523-1739.1999.97343.x

WALKER B (1923) The Ancylidae of South Africa. Privately published.

WITTMANN, GTW and FÖRSTNER U (1975) Metal enrichment of sediments in inland waters - the Hartbeespoort Dam. Water SA 1 76-82. 